\title{
Angiotensin-2 receptors (ATI-R and AT2-R), new prognostic factors for renal clear-cell carcinoma?
}

\section{T Dolley-Hitze',2,6, F Jouan',6, B Martin', S Mottier', J Edeline', O Moranne ${ }^{5}$, P Le Pogamp ${ }^{2}$, M-A Belaud-Rotureau', J-J Patard ${ }^{3}$, N Rioux-Leclercq ${ }^{1,4}$ and C Vigneau*,1,2}

'CNRS UMR606 I/IFR I 40, Faculté de Médecine Université de Rennes I, 2 avenue du professeur Léon Bernard, CS343 I7, 35043 Rennes Cedex, France; ' 2 Senvice de Néphrologie, CHU Pontchaillou - 2 rue Henri Le Guilloux, 35033 Rennes Cedex, France; ${ }^{3}$ Service d'Urologie, CHU Pontchaillou - 2 rue Henri Le Guilloux, 35033 Rennes Cedex, France; ${ }^{4}$ Senvice d'Anatomie et Cytologie Pathologiques - CHU Pontchaillou - 2 rue Henri Le Guilloux, 35033 Rennes Cedex, France; ${ }^{5}$ Service de Néphrologie, CHU Nice. Hôpital Pasteur, 2 voie Romaine, 06000 Nice, France

BACKGROUND: The growth factor Angiotensin-2 signals through Angiotensin receptor type I (ATI-R) in a broad range of cell types and tumours and through the type-2 receptor (AT2-R) in a more restricted group of cell types. Although numerous forms of cancer have been shown to overexpress ATI-R, expression of ATI-R and AT2-R by human renal clear-cell carcinoma (RCCC) is not well understood. In this study, the expression of both angiotensin receptors was quantified in a retrospective series of RCCC and correlated with prognostic factors.

METHODS: Angiotensin receptor type I and AT2-R expressions were quantified on tumour tissues by immunohistochemistry (IHC), western blot and quantitative reverse transcriptase PCR (qRT-PCR). $॥$ C results were correlated to Fuhrman's grade and patient progression-free survival (PFS).

RESULTS: A total of 84 RCCC were analysed. By IHC, ATI-R and AT2-R were expressed to a greater level in high-grade tumours (ATI-R: $P<0.001$, AT2-R: $P<0.00 I$ ). Univariate analysis showed a correlation between PFS and ATI-R or AT2-R expression $(P=0.00 \mathrm{I})$. By multivariate analysis, only AT2-R expression correlated with PFS $(H R I .02 \mathrm{I}, P=0.006)$ and cancer stage $(P<0.00 \mathrm{I})$. By western blot, ATI-R and ATI-R were also found to be overexpressed in higher Fuhrman's grade $(P<0.01$ and $P=0.00 \mathrm{I}$ respectively). By qRT-PCR, ATI-R but not AT2-R mRNA were downregulated $(P=0.001$ and $P=0.1 \mid 8$, respectively).

CONCLUSION: Our results show that ATI-R and AT2-R proteins are overexpressed in the most aggressive forms of RCCC and that AT2-R expression correlates with PFS. ATI-R or AT2-R blockage could, therefore, offer novel directions for anti-RCCC therapy. British Journal of Cancer (2010) 1 03, 1698- 1705. doi:I0.1038/sj.bjc.6605866 www.bjcancer.com

(C) 2010 Cancer Research UK

Keywords: renal cell carcinoma; ATI-R; AT2-R; Angiotensin-2; prognostic factor

Renal clear-cell carcinoma (RCCC) accounts for 3\% of adult cancers. Surgical resection is the mainstay of treatment, but about $40 \%$ of patients develop distant metastases with poor prognosis. The renin-angiotensin system (RAS) is well-known for its regulation of arterial pressure. RAS blockage represents an important target in the treatment of hypertension (HTA) and cardiac failure through two pharmacological classes: angiotensinconverting enzyme inhibitors (ACEi) and angiotensin-receptor blockers (ARB). The intracellular effects of angiotensin-2 (ATII) are principally mediated by two receptors: Angiotensin- 2 receptor type 1 (AT1-R) and Angiotensin-2 Receptor type 2 (AT2-R).

Physiologically, both receptors are widely expressed, principally by heart, vessels, brain and kidney. Both receptors are involved during renal development (Norwood et al, 1997). In normal adult kidneys, they localise in the cortex where AT1-R mRNA is expressed 8-10 fold more than AT2-R mRNA (Matsubara et al, 1998). Angiotensin receptor type 1 is strongly expressed by

\footnotetext{
*Correspondence: Dr C Vigneau; E-mail: cecile.vigneau@chu-rennes.fr

${ }^{6}$ These authors contributed equally to this work

Revised 16 July 2010; accepted 3 August 2010
}

mesangial cells (Goldfarb et al, 1994; Arendshorst et al, 1999) and interlobular endothelial arterial cells (Matsubara et al, 1998; Arendshorst et al, 1999). In contrast, AT2-R is expressed more strongly by pre-glomerular endothelial arterial cells and by interlobular endothelial arterial cells (Goldfarb et al, 1994; Matsubara et al, 1998; Arendshorst et al, 1999). Both receptors are also expressed by proximal tubular cells (Weerackody et al, 1997).

Angiotensin-2 receptors regulate many physiological processes. The main function of ATII is vasoconstriction, as one of the final steps of RAS (Arendshorst et al, 1999). In many cells, ATII, through AT1-R facilitates cellular proliferation and angiogenesis (Stoll et al, 1995; Li et al, 2008), whereas AT2-R has antiproliferative properties (Stoll et al, 1995; Nouet and Nahmias, 2000). Moreover in the kidney, ATII induced tubular cell hypertrophia and proliferation through AT1-R (Chatterjee et al, 1997). In addition, in the kidney, ATII, through AT2-R, triggered tubular cell proliferation, angiogenesis and apoptosis (Cao et al, 2000). As RCCC cells are developed from tubular renal cells, AT1-R and AT2-R may also be involved in RCCC development.

Recently, overexpression of AT1-R by in vitro cultured breastcarcinoma cells (Herr et al, 2008; Rhodes et al, 2009), pancreatic adenocarcinoma cells (Arafat et al, 2007) or hepatocarcinoma cells 
(Yoshiji et al, 2002) was reported. Overexpression of AT1-R has also been demonstrated in vivo in different tumours, including: oestrogen receptor positive breast cancers (Rhodes et al, 2009), glioblastomas (Juillerat-Jeanneret et al, 2004), ovarian cancers (Suganuma et al, 2005), squamous cell carcinomas of the skin (Takeda and Kondo, 2001) and gastric cancers (Rocken et al, 2007). Despite its anti-proliferative effect, AT2-R was also found to be overexpressed by several cancers such as astrocytomas (Arrieta et al, 2008) or lung tumours (Tamura et al, 2008) in vivo.

Several clinical series examined the link between AT1-R or AT2-R overexpression and patient prognosis. Angiotensin receptor type 1 and AT2-R overexpression was linked to worse prognosis (Arrieta et al, 2008) in astrocytomas, suggesting a role for these receptors on carcinogenesis and/or neoangiogenesis.

Little is known about the expression and role(s) of ATII receptors in RCCC. An initial study described expression in RCCC by autoradiography but did not correlate this expression with tumour aggressiveness (Goldfarb et al, 1994). A second study showed on a mouse model that ARB could prevent the development of RCCC pulmonary metastasis (Miyajima et al, 2002). The objective of our study was to quantify the expression of both ATII receptors in RCCC and correlate this expression with well-known prognostic factors and progression-free survival (PFS).

\section{MATERIALS AND METHODS}

This study was designed retrospectively by using the Rennes database for RCCC from 2002 to 2006 and by exploring expression of angiotensin-2 receptors by several methods. All patients undergoing nephrectomy for sporadic RCCC in Rennes are included in a clinical and histological database, after giving informed consent.

\section{Tumours specimens}

Immediately after macroscopic examination, small samples are collected from surgical specimens, frozen in liquid nitrogen and stored at $-80^{\circ} \mathrm{C}$ for RNA and protein extraction. Tumour tissues were also preserved in $10 \%$ formalin and embedded in paraffin for immunostaining. For protein or RNA extractions, $5 \mu \mathrm{m}$ tissue sections were cut before and after the samples. Hemotoxylineosin staining was performed on sections to confirm or revise the Fuhrman's grade and only controlled samples were included. If necrosis, fibrosis or non-tumourous kidney tissue was above $10 \%$ of total tissue examined, the corresponding sample was excluded from analysis.

\section{Pathological, histological and clinical data}

In this study, TNM (Tumour, Node and Metastasis) score, tumour size and Fuhrman's grade were extracted from Rennes database for RCCC. These data are routinely evaluated for each tumour. Fuhrman's grade, a nuclear grading system, is based on nuclear size, shape and prominence of nucleoli. This score is determined in the most aggressive tumour area and represents one of the key determinants of RCCC-specific survival (Fuhrman et al, 1982). Several clinical data were also used such as gender, age, delay between surgery and progression or death and performance status at surgical time (ECOG scale (Eastern Cooperative Oncology Group) (Oken et al, 1982)).

\section{Immunohistochemistry (IHC)}

For immunostaining, a representative paraffin block with the highest Furhman's grade was selected; $5 \mu$ m-thick sections were cut from each block. Immunostaining was performed on formalinfixed, paraffin-embedded tissues using the labelled-polymer method. Slides were dewaxed and rehydrated using xylol and ethanol, respectively, and transferred in hot citrate buffer $0.01 \mathrm{moll}^{-1}$ and $\mathrm{pH} 6$ (cooked in $100^{\circ} \mathrm{C}, 40 \mathrm{~min}$ ), left in the hot buffer for 20 additional minutes and transferred into PBS-T $0.1 \%$ buffer for $5 \mathrm{~min}$. Endogenous peroxidase was quenched in 3\% hydrogen peroxide for $10 \mathrm{~min}$ and slides were again transferred into PBS-Tween $0.1 \%$ buffer for $5 \mathrm{~min}$. After pre-incubation with FCS (fetal calf serum) $10 \%$ for 20 min (for AT1-R), the slides were incubated with a dilution of 1:500 (in PBS-T 1\% FCS) rabbit polyclonal anti AT1-R antibody (Santa-Cruz, NT, USA; sc-1173) and a dilution of 1:100 (in primary antibody-diluting buffer) goat polyclonal anti AT2-R Antibody (Santa-Cruz; K15, sc-48452) at room temperature for $2 \mathrm{~h}$. Control without primary antibody was always performed at the same time with PBS-T 1\% SVF (AT1-R), and primary antibody-diluting buffer (AT2-R). Sections were rinsed in PBS-T and incubated with polyclonal rabbit anti-goat immunoglobulin (1:200 dilution-30 min) for AT2-R only, followed by incubation with HRP (horseradish peroxidase)-labelled polymer conjugated with secondary antibodies (Envision + Dual link system-HRP, DAKO). Diaminobenzidine was used as a chromogen in the presence of hydrogen peroxide. Hematoxylin was used as a couterstainer. Study specimens were evaluated by a single uropathologist (NRL) (Microscope: olympus BX51, camera: olympus DP70). Immunostaining of AT1-R and AT2-R was expressed as the percentage of AT1-R/AT2-R-positive tumour cells by scoring at least 1000 cells.

\section{Western blot analysis}

Protein lysates were prepared by treating frozen tissues with RIPA (radio immuno precipitation assay) buffer (consisting of $50 \mathrm{mM}$ Tris-HCL pH8, $150 \mathrm{mM} \mathrm{NaCl}, 0,1 \%$ SDS and $1 \% \mathrm{NP} 40,0,5 \% \mathrm{Na}$ deoxycholate, $1 \mathrm{mM}$ DTT and $10 \mu \mathrm{g} \mathrm{ml}^{-1}$ protease inhibitors) at $4{ }^{\circ} \mathrm{C}$ (30-60 min). Tissue lysates were then centrifugated at $13000 \mathrm{~g}$ for $30 \mathrm{~min}$ and supernatants were harvested. Protein concentrations were determined by the Bradford method. A volume of $25 \mu \mathrm{g}$ of protein (boiled at $95^{\circ} \mathrm{C}$ ) were separated by $12.5 \%$ SDS polyacrylamide gel electrophoresis (SDS-PAGE) and transferred to a nitrocellulose membrane. Each membrane was blocked with phosphate buffer saline (PBS) containing 5\% skim milk for $2 \mathrm{~h}$, and incubated at $4{ }^{\circ} \mathrm{C}$ overnight with 1:500 of AT1-R (Santa-Cruz; sc-1173) or 1:200 of AT2-R (Santa-Cruz; H 143, sc-9040). The membrane was subsequently incubated for $1 \mathrm{~h}$ at room temperature with fluorescent-labeled secondary antibody (IRDye Tmn 800dilution 1:5000) and analysed using infrared imaging system (Odyssey-Biosciences). $\beta$-Actin was used as loading and blotting controls and detected by anti-human $\beta$-actin (clone AC-15, Sigma, Lyon, France).

\section{RNA (ribonucleic acid) purification and quantitative RT - PCR (reverse transcript PCR)}

Total RNA was extracted from tissues with the Genelute Mammalian total RNA Miniprep (RTN-70 Sigma), and treated with DNase I to avoid genomic DNA contamination. The RNA product was quantified by absorbance at $260 \mathrm{~nm}$. The integrity of RNA samples was controlled by analysis on bioanalyzer with RNA 6000 Nano assay Labship (Agilent Technologies, Santa Clara, CA, USA) and ratio integral number (RIN) was calculated. Only RNA with RIN $>8$ were further processed and used for cDNA synthesis. A volume of $1 \mu \mathrm{g}$ of total RNA was transcribed into cDNA using high capacity cDNA Archive kit (Applied Biosystems, Foster City, CA, USA).

Quantitative PCR was performed with the PCRq 7900 HT (Applied biosystems) using power SYBR Green PCR Master mix (Applied biosystems). The reaction mixture contained $5 \mu \mathrm{l}$ of master mix, $0.3 \mu \mathrm{l}$ of each primer $(10 \mu \mathrm{M})$ and $2 \mu \mathrm{l} \mathrm{cDNA}$ (diluted $1: 40)$ for a total reaction volume of $10 \mu \mathrm{l}$. Oligonucleotide primers were synthesised by Eurogentec (Angers, France). The sequences 
of these primers were as follows: (forward) $5^{\prime}$-ATG-ATT-CCAGCG-CCT-GAC-3' and (reverse) 5'-GGT-CCA-GAC-GTC-CTGTCA-CT-3' for AT1-R, (forward) 5'-GGT-TTC-TAG-CAT-ATACAT-CTT-CAA-CCT-3' and (reverse) 5'-GCC-CAT-AGA-GGAAGA-GTA-GCC-3' for AT2-R, (forward) $5^{\prime}$-GGT-CCT-TTC-ACCAGC-AAG-CT- ${ }^{\prime}$ and (reverse) $5^{\prime}$-GCT-TTC-CTT-GGT-CAG-GCAGTA- $3^{\prime}$ for HPRT. The programme was as follows: an initial step at $95^{\circ} \mathrm{C}$ for $10 \mathrm{mn}$ and then 40 cycles of $95^{\circ} \mathrm{C}$ for $15 \mathrm{~s}$ and $60^{\circ} \mathrm{C}$ for $60 \mathrm{~s}$. Regression curves were drawn for each sample, and its relative amount was calculated from the threshold with the instrument's software (SDS 2.0) according to the manufacturer's instructions. Relative expression levels of the target genes were normalised mean of an internal control gene, HPRT.

\section{Statistical analysis}

Progression-free survival was determined from the date of surgery to the date of cancer progression or the last follow-up. Nonparametric tests (Kruskal Wallis) were used to compare means and proportions. Estimates of the cumulative survival distributions were calculated according to the Kaplan-Meier method and logrank tests were used to compare the differences between groups. A Cox proportional-hazard regression model was used to test the independent effects of clinical and pathological variables on survival. Graphical methods suggested that the proportionalhazards assumption was reasonable for all selected variables. A stepwise selection procedure was used to select the final optimal model. All $P$-values were two-sided and $P<0.05$ was considered to indicate significance. All analyses were conducted with the Statistical Package for the Social Sciences, version 16.0 (SPSS Inc., Chicago, IL, USA).

\section{RESULTS}

A total of 84 patients who underwent nephrectomy between 2002 and 2006 were included in our study. All protein and RNA extracts from frozen samples corresponding to IHC Fuhrman's grade were selected for western blot and qRT-PCR experiments $(n=55)$. Paraffin sections were done on all samples.

In all, 50 men and 34 women were included, with a mean age of $63.7 \pm 11.3$ years. At the time of surgery, 56 patients were ECOG 0 and 28 ECOG 1 ; three tumours were Fuhrman's grade $1(3.5 \%)$, 32 grade $2(37.6 \%), 26$ grade $3(30.9 \%)$ and 23 grade $4(27.3 \%)$. A total of 22 patients $(26.2 \%)$ had metastases at the time of surgery, as well as $11(13.1 \%)$ had lymph node involvement. Median

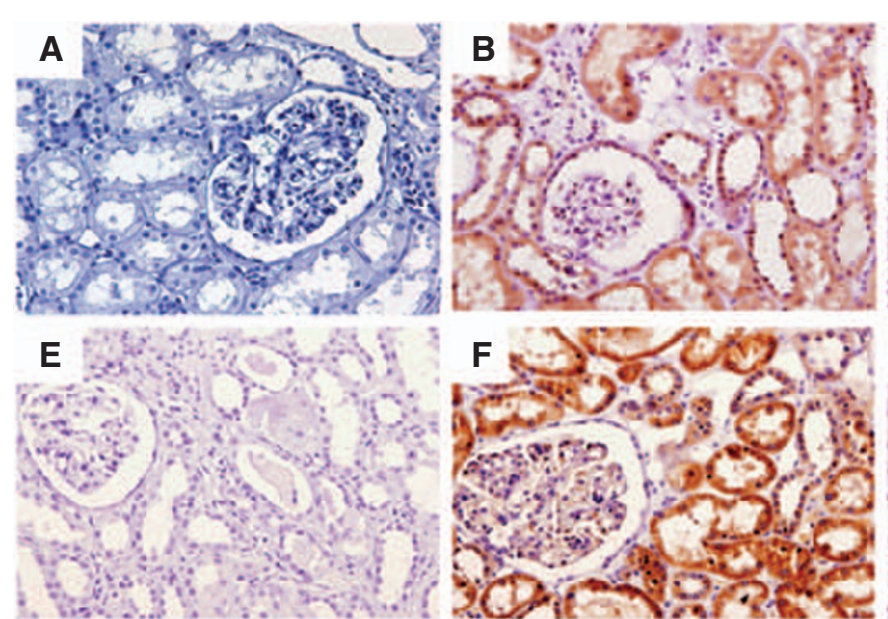

tumour size was $7.0 \pm 4.10 \mathrm{~cm}$. No patient received anti-angiogenic therapy or chemotherapy before surgery. Mean follow-up was 30 months ( \pm 18 months).

For the statistical analysis grade 1 and 2 were combined because of low number of grade 1 tumours.

\section{Immunohistochemistry}

Localisation of AT1-R and AT2-R was described on tumour tissue and normal surrounding tissue (Figure 1). Angiotensin receptor type 1 stained all tubular cells, podocytes, epithelial cells of Bowman's capsule and vascular smooth-muscle cells in the normal cortex. AT2-R cortical staining localised only on tubular cells. Tumour cells, as well as normal renal cells, exhibited cytoplasmic staining but not membrane or nuclear immunostaining.

A total of 82 tumours were stained for AT1-R (3 Fuhrman's grade 1, 31 grade 2, 26 grade 3 and 22 grade 4 ) and 76 for AT2-R (3 Fuhrman's grade 1, 30 Fuhrman's grade 2, 24 Fuhrman's grade 3 and 19 Fuhrman's grade 4). For each sample, the ratio of positive tumour cells/total tumour cells was expressed as a percentage. Angiotensin receptor type 1 median ratio was $12.5 \%$ and AT2-R one was $10 \%$. Figure 2 shows that AT1-R was overexpressed by Fuhrman's 4 RCCC compared with other grade tumours $(P<0.001$; panel A). Angiotensin type-2 receptor was also overexpressed by Fuhrman's 4 RCCC $(P<0.001$; panel B).

\section{Western blot}

Frozen tumours were included in the WB experiments to confirm IHC results by another semi-quantitative method (Figure 3 ). A total of 47 frozen samples (2 Fuhrman's grade 1, 15 grade 2, 19 grade 3 and 11 grade 4) containing tumour tissue alone were analysed. Samples with significant proportion of non-tumour tissue or fibrosis or necrosis (more than 10\%) were excluded. The AT1-R was overexpressed by the higher Fuhrman's grade tumours as shown in Figure $3(P<0.001)$; panel A). A total of 51 samples were included to quantify AT2-R by WB (3 Fuhrman's grade 1, 18 grade 2, 20 grade 3 and 10 grade 4 ). Angiotensin type- 2 receptor was also significantly increased in high Fuhrman's grade tumours $(P=0.001$; panel $\mathrm{B})$.

\section{qRT - PCR}

By RT-PCR, AT1-R expression was analysed on 55 samples (3 grade 1 tumours, 17 grade 2, 17 grade 3 and 18 grade 4).

Figure I Staining by IHC on non-tumorous kidney tissue and renal cell carcinoma. Top panel, ATI-R IHC: (A) negative control, (B) staining of nontumorous renal tissue, positive on tubular and Bowman's capsule cells, (C) Fuhrman's grade I renal carcinoma with no staining, (D) Fuhrman's grade 4 renal carcinoma with positive staining. Bottom panel, AT2-R IHC: (E) negative control, (F) staining of non-tumorous renal tissue on tubular cells, (G) Fuhrman's grade I renal carcinoma with no staining, $(\mathbf{H})$ Fuhrman's grade 4 renal carcinoma with intense staining. $\times 200$ magnification for all images 

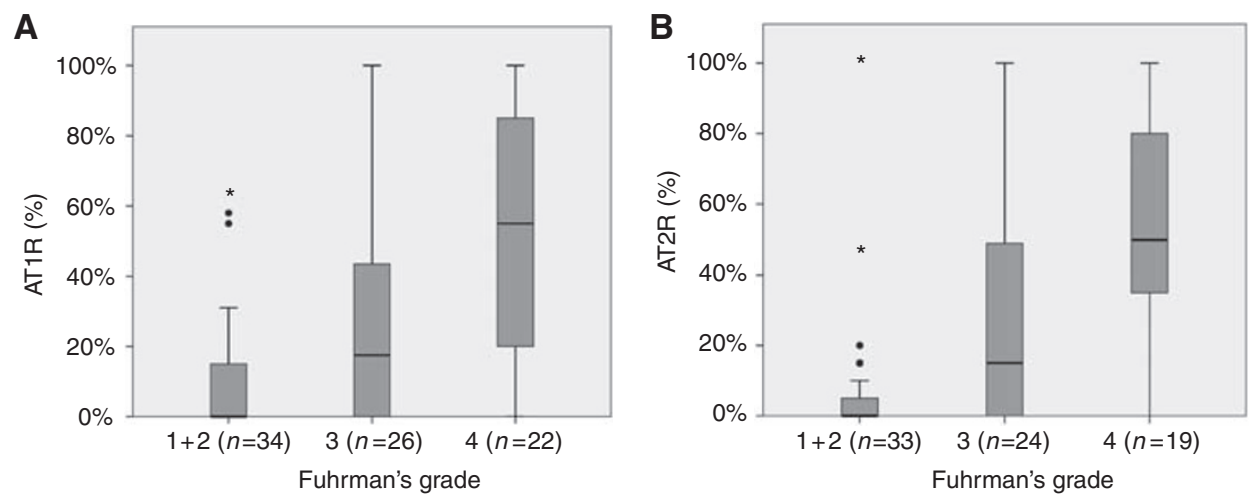

Figure 2 Angiotensin receptor type I $(\mathbf{A})$ and AT2-R (B) expression by $\mathrm{HC}$ according to Fuhrman's grade. Results are expressed as percentage of ATI-R/AT2-R-positive tumour cells. Median expression is $12.5 \%$ for ATI-R and I0\% for AT2-R. Angiotensin receptor type I ( $n=82$ tumours) and AT2-R ( $n=76$ tumours) are overexpressed by the most aggressive tumours ( $P<0.00 \mathrm{I}$ for both).
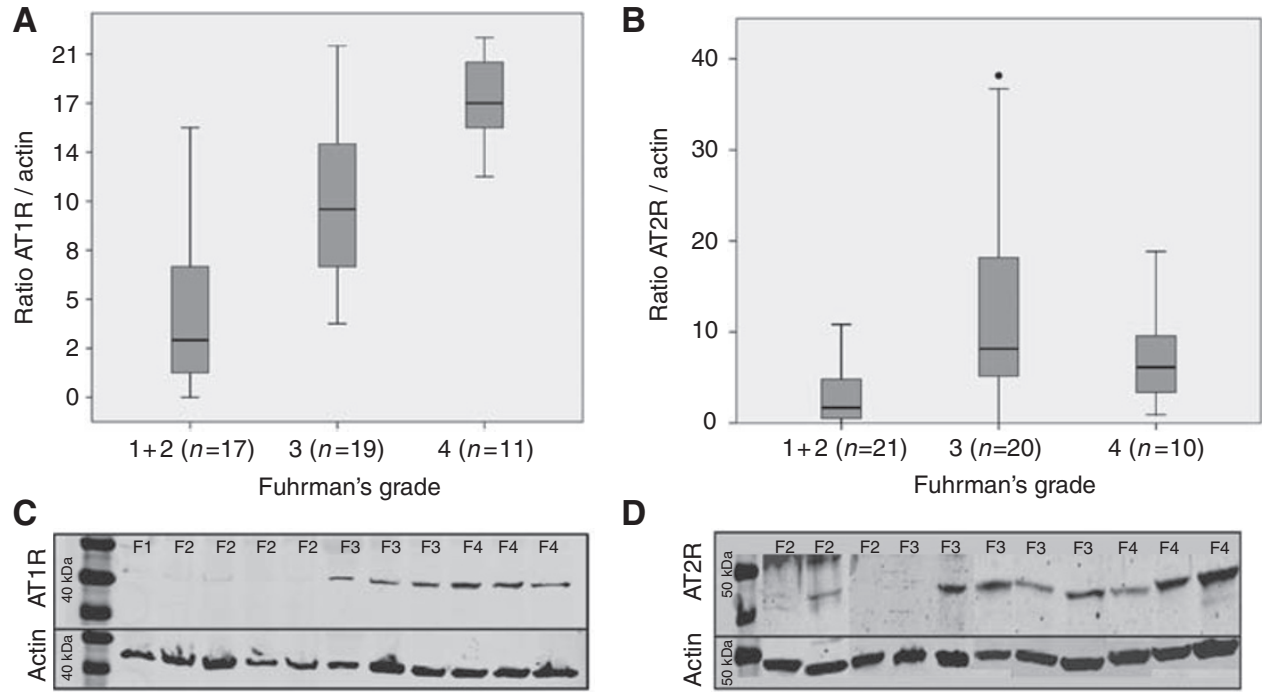

D

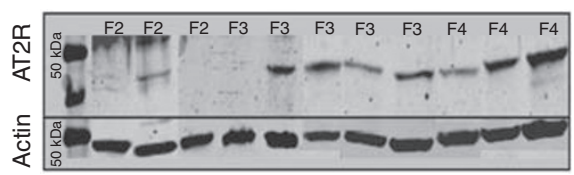

Figure 3 Quantification by western blot of ATI-R/Actin ratio $(\mathbf{A}, \mathbf{C})$ and AT2-R/Actin ratio $(\mathbf{B}, \mathbf{D})$. Angiotensin receptor type I is over expressed by the higher Fuhrman's grades tumours $(P<0.00 \mathrm{I}, n=47)$, as well as AT2-R $(P=0.00 \mathrm{I}, n=5 \mathrm{I})$. F for Fuhrman grade.
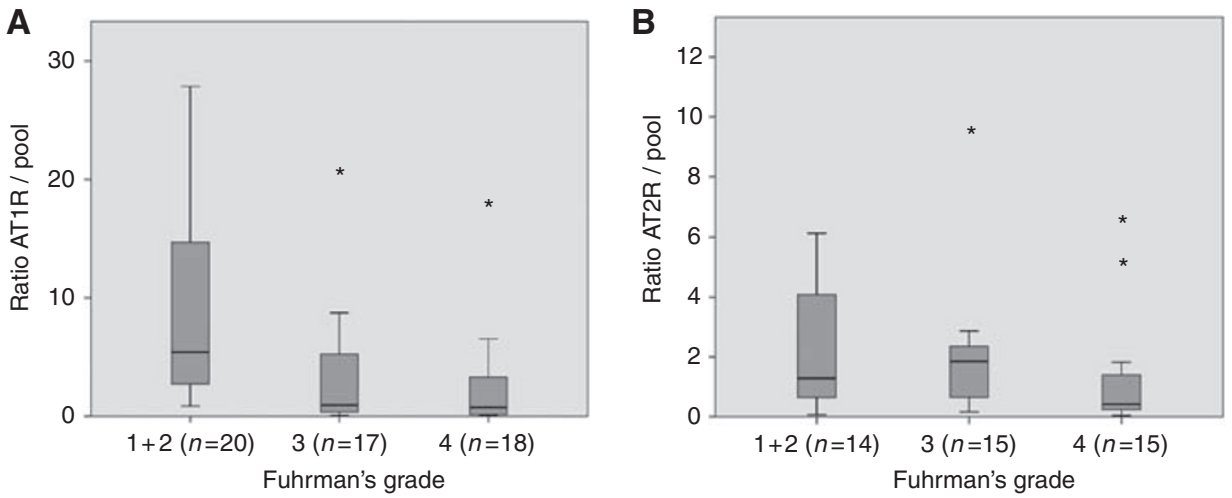

Figure 4 Reverse transcription-PCR of ATI-R and AT2-R according to Fuhrman's grade. Angiotensin receptor type I expression is significantly decreased according to the Fuhrman's grade (panel $\mathbf{A}, P=0.001, n=55$ ). Angiotensin type 2 receptor is not differentially expressed between different Fuhrman's grades (panel $\mathbf{B} ; P=0.118, n=44$ ).

It was significantly decreased according to the Fuhrman's grade (Figure 4 - panel A, $P<0.001$ ). However, on the 44 tumours suitable for analysis (2 grade 1, 12 grade 2, 15 grade 3 and 15 grade 4), AT2-R mRNA was not differentially expressed according to Fuhrman's grade (panel $\mathrm{B} ; P=0.118, \mathrm{NS}$ ).

\section{Survival, univariate and multivariate analyses}

Progression-free survival was assessed by the Kaplan-Meier method and compared by log-rank test according to the level of $\mathrm{AT} 1-\mathrm{R}$ and AT2-R ( $\leqslant$ or $>$ median expression determined by IHC 
method). Figure 5 shows that PFS was better when AT1-R was expressed below $12.5 \%$ (median) by IHC $(P=0.006$; panel A) and AT2-R below $10 \%$ (median) $(P=0.001$; panel B). Univariate and multivariate analysis results are presented in Table 1 for AT1-R and in Table 2 for AT2-R. By univariate analysis, PFS correlated with AT1-R $(P=0.001)$, as well as stage $(\mathrm{T} 1 / 2$ vs T3/4, $P<0.001)$, nodal invasion $(P<0.001)$, distant metastasis $(P<0.001)$, tumour size ( $\leqslant$ or $>7 \mathrm{~cm}, P=0.001)$, Fuhrman's grade (F1/2 vs F3/4 $P<0.001)$ but not ECOG stage $(P=0.239)$. By multivariate analysis, AT1-R did not correlate with PFS (NS) on the contrary to tumour stage $(P<0.001)$, Fuhrman's grade $(P=0.044)$, nodal invasion $(P=0.003)$ and ECOG stage $(P=0.005)$. For AT2-R, univariate analysis showed that PFS correlated with AT2-R $(P=0.001)$, as well as tumour stage (T1/2 vs T3/4, $P<0.001)$, nodal invasion $(P=0.002)$, distant metastasis $(P<0.001)$, tumour size $(<$ or $>7 \mathrm{~cm}, P=0.001)$, Fuhrman's grade $(\mathrm{F} 1 / 2$ vs $\mathrm{F} 3 / 4 \quad P<0.001)$ but not ECOG stage (0.253). By multivariate analysis, AT2-R was still correlated with PFS $(P=0.006)$ as tumour stage $(P<0.001)$.

\section{DISCUSSION}

Our study shows that both AT1-R and AT2-R protein expression correlate with RCCC aggressiveness and PFS. This relationship
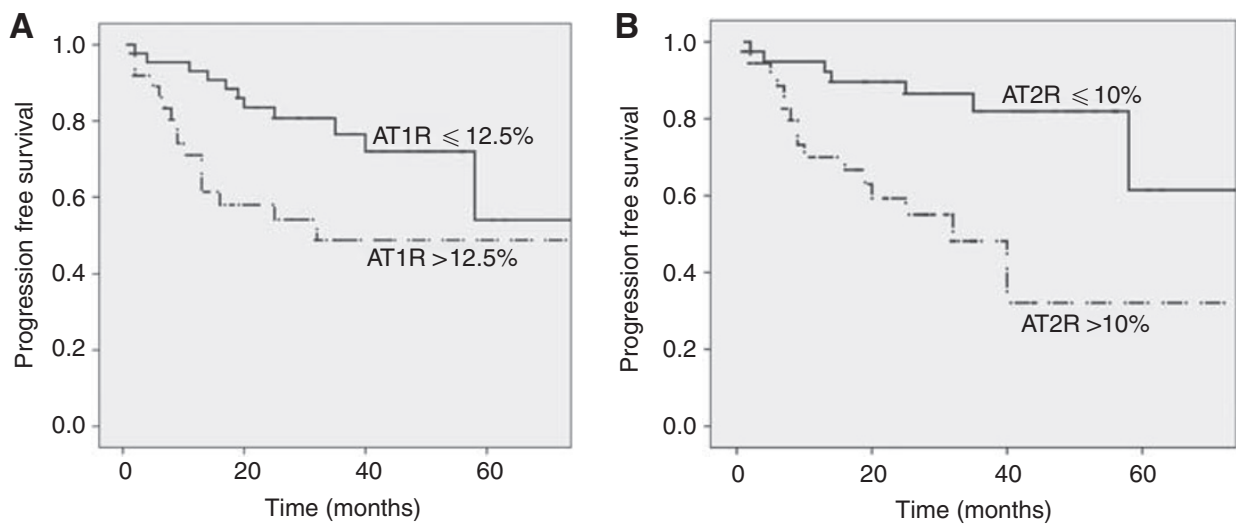

Figure 5 Patient progression-free survival curves according to ATI-R $(\mathbf{A})$ and $A T 2-R(\mathbf{B})$ level, assessed by $I H C$. (A) ATI-R $\leqslant$ median (plain line) or $>$ median (dash) $P=0.006 ;$ (B) ATI-R $\leqslant$ median (plain line) or $>$ median (dash) $P=0.00$ I (log-rank test).

Table I Variables associated with progression-free survival in univariate analysis and with Cox proportional hazards regression model for ATI-R expressed by $\mathrm{HC}$

\begin{tabular}{|c|c|c|c|c|}
\hline $\begin{array}{l}\text { Variables } \\
\text { (No. of } \\
\text { patients) }\end{array}$ & $\begin{array}{l}\text { Percentage of } \\
\text { progression }\end{array}$ & $\begin{array}{c}P \text { (univariate } \\
\text { analysis) }\end{array}$ & $\begin{array}{c}\text { Multivarate } \\
\text { analysis } \\
\text { hazard ratios } \\
(95 \% \mathrm{Cl})\end{array}$ & $\boldsymbol{P}$ \\
\hline \multicolumn{5}{|l|}{ Stage } \\
\hline $\mathrm{TI} / 2$ & (45) $11.1 \%$ & & & \\
\hline $\mathrm{T} 3 / 4$ & (39) $61.5 \%$ & $<0.001$ & 9.841 & $<0.001$ \\
\hline \multicolumn{5}{|l|}{ Nodal invasion } \\
\hline No & (73) $28.7 \%$ & & & \\
\hline Yes & (II) $72.7 \%$ & $<0.001$ & 4.245 & 0.003 \\
\hline \multicolumn{5}{|c|}{ Distant metastasis } \\
\hline No & (47) $22.6 \%$ & & & \\
\hline Yes & (37) $68.2 \%$ & $<0.001$ & & NS \\
\hline Tumor size & & 0.001 & & NS \\
\hline$\leqslant 7 \mathrm{~cm}$ & (44) I5.9\% & & & \\
\hline$>7 \mathrm{~cm}$ & (40) $55 \%$ & & & \\
\hline \multicolumn{5}{|c|}{ Fuhrman's grade } \\
\hline $1+2$ & (35) $8.5 \%$ & & & \\
\hline $3+4$ & (49) $53.0 \%$ & $<0.001$ & 3.688 & 0.044 \\
\hline \multicolumn{5}{|c|}{$A T I R \leqslant$ or $>12.5 \%$} \\
\hline$\leqslant 12.5 \%$ & (4I) $25 \%$ & & & \\
\hline$>12.5 \%$ & (43) $44.7 \%$ & 0.001 & & NS \\
\hline \multicolumn{5}{|l|}{ ECOG } \\
\hline 0 & (56) $28.5 \%$ & & & \\
\hline I or more & (28) $46.4 \%$ & 0.239 & 3.487 & 0.005 \\
\hline
\end{tabular}

Abbreviations: $A T I R=$ angiotensin type I receptor; $C l=$ confidence interval; $\mathrm{ECOG}=$ eastern cooperative oncology group performance status.
Table 2 Variables associated with progression-free survival in univariate analysis and with Cox proportional hazards regression model for AT2-R expressed by $\mathrm{HC}$

\begin{tabular}{|c|c|c|c|c|}
\hline $\begin{array}{l}\text { Variables } \\
\text { (No. of } \\
\text { patients) }\end{array}$ & $\begin{array}{l}\text { Percentage } \\
\text { of progression }\end{array}$ & $\begin{array}{l}P \text { (univariate } \\
\text { analysis) }\end{array}$ & $\begin{array}{c}\text { Multivarate } \\
\text { analysis } \\
\text { Hazard ratios } \\
(95 \% \mathrm{Cl})\end{array}$ & $P$ \\
\hline \multicolumn{5}{|l|}{ Stage } \\
\hline $\mathrm{TI} / 2$ & \% $11.1 \%$ & & & \\
\hline $\mathrm{T} 3 / 4$ & (39) $61.5 \%$ & $<0.001$ & | 4.297 & $<0.001$ \\
\hline \multicolumn{5}{|l|}{ Nodal invasion } \\
\hline No & (73) $28.7 \%$ & & & \\
\hline Yes & (II) $72.7 \%$ & 0.002 & & NS \\
\hline \multicolumn{5}{|c|}{ Distant metastasis } \\
\hline No & (47) $22.6 \%$ & & & \\
\hline Yes & (37) $68.2 \%$ & $<0.001$ & & NS \\
\hline Tumor size & & 0.001 & & NS \\
\hline$\leqslant 7 \mathrm{~cm}$ & (44) $15.9 \%$ & & & \\
\hline$>7 \mathrm{~cm}$ & (40) $55 \%$ & & & \\
\hline \multicolumn{5}{|c|}{ Fuhrman's grade } \\
\hline $1+2$ & (35) $8.5 \%$ & & & \\
\hline $3+4$ & (49) $53.0 \%$ & $<0.001$ & & NS \\
\hline \multicolumn{5}{|c|}{$A T 2 R \leqslant$ or $>10 \%$} \\
\hline$\leqslant 10 \%$ & (42) $17.5 \%$ & & & \\
\hline$>10 \%$ & (42) $47.2 \%$ & 0.001 & 1.021 & 0.006 \\
\hline \multicolumn{5}{|l|}{ ECOG } \\
\hline 0 & (56) $28.5 \%$ & & & \\
\hline I or more & (28) $46.4 \%$ & 0.253 & & NS \\
\hline
\end{tabular}

Abbreviations: $A T I R=$ angiotensin type I receptor; $\mathrm{Cl}=$ confidence interval; $E C O G=$ eastern cooperative oncology group performance status. 
suggests a role for these two receptors in regulating tumour growth and/or neoangiogenesis and a potential therapeutic effect of receptor antagonists.

AT1-R overexpression has already been described in other cancers but not previously for RCCC. This correlation might be because of a direct effect of ATII on tumour cells. Indeed, ATII through AT1-R can activate tumour cell proliferation through at least two simultaneous mechanisms: PI3-kinase/Akt pathway (Zhao et al, 2010) and EGFR (epithelial growth factor receptor) trans-activation (Fujiyama et al, 2001; Greco et al, 2003; Uemura et al, 2003). Secondly, ATII through AT1-R can induce an increased expression and production in vascular endothelial growth factor (VEGF) inducing neo-angiogenesis (Arafat et al, 2007; Kosaka et al, 2010). Induction might be triggered by stabilisation of hypoxia inducible factor- $1 \alpha$ (HIF $1 \alpha)$, as shown in prostate cancer model (Richard et al, 2000; Ino et al, 2006; Kosaka et al, 2010). Positive correlation between AT1-R expression and VEGF production has been showed in ovarian cancer, in vivo. Moreover, ATII through AT1-R reduces tumour cell adhesion although reducing invasion of the basement membrane (Puddefoot et al, 2006). Lastly, in a mouse model of gastric cancer AT1-R could trigger lymphangiogenesis (Wang et al, 2008).

AT2-R is overexpressed by some cancers such as gastric cancers (Rocken et al, 2007) though its role in carcinogenesis remains controversial. Under physiological conditions, AT2-R has antiproliferative properties (Fujiyama et al, 2001), whereas during carcinogenesis, AT2-R can induce an invasive phenotype, for example, in gastric cancer (Carl-McGrath et al, 2007), or prevent cell proliferation (Bose et al, 2009). However, AT2-R has been shown to counteract the effects of ATII mediated by AT1-R, and might be upregulated upon prolonged ATII stimulation (Nouet and Nahmias, 2000). High expression of AT2-R in RCCC could be either a consequence of AT1-R overexpression or of the high circulating level of ATII and/or may have specific angiogenesis effects as in gastric cancer. Even more, in kidney, AT2-R can physiologically induce tubular cell proliferation during development or after kidney injury (Cao et al, 2000). As RCCC develops from tubular cells, AT2-R overexpression may be one of the mechanisms by which tubular cell proliferation develops into carcinogenesis. The strong correlation between tumour aggressiveness, PFS and AT2-R expression in our study indeed supports the hypothesis for a proliferative effect of AT2-R in RCCC, more than in other type of cancers. Specific in vitro studies, using anti AT1-R and/or AT2-R inhibitors on RCCC-cultured cells will help to illuminate the role(s) of AT2-R in renal carcinogenesis.

In our ex vivo study, dissociation between AT1-R and AT2-R protein expression and RNA synthesis was also observed. As the staining of both receptors was mainly expressed by tumour cells as detected by IHC, and because the tumour nature of tissue analysed was controlled, we suggest that AT1-R and AT2-R mRNA amplified were indeed synthesised by tumour cells. We also suggest that post-transcriptional or post-translational mechanisms, never described in other type of cancer, might be involved in RCCC. The underlying mechanisms of receptor synthesis, internalisation, sequestration and inactivation are incompletely understood (Arendshorst et al, 1999).

The correlation between RAS and RCCC opens new potential therapeutic strategies in RCCC. Angiotensin-receptor blockers and ACEi are highly prescribed and well tolerated anti-hypertensive therapies. Large epidemiological studies suggest potential protective effects against cancer risk even if results remain controversial (Lever et al, 1998; Friis et al, 2001). Angiotensin-receptor blockers and ACEi could act on tumour progression by two different mechanisms: inhibition of cancer proliferation and/or inhibition of neovascularization. In experimental studies on different cancer types, ARB or ACEi showed anti-proliferative effects: in breast cancer cells (Puddefoot et al, 2006; Rhodes et al, 2009) in human melanoma xenograft model (de Groot-Besseling et al, 2004), in murine hepatocellular carcinoma (Noguchi et al, 2003), in colorectal cancer liver metastases (Neo et al, 2007), on pancreatic cancer cells (Arafat et al, 2007) or on lung metastases of mouse RCCC (Miyajima et al, 2002). Inhibition of tumour growth involves the decreased expression of VEGF. It has been shown for pancreatic cancer (Arafat et al, 2007; Noguchi et al, 2009) and for prostate cancer (Kosaka et al, 2010). The inhibition of endothelial cell tubular formation (Yoshiji et al, 2005) and/or apoptosis of endothelial or tumour cells (De la Iglesia Inigo et al, 2009) were also described. In a recent model of murine melanoma graft, ARB-induced tumour growth decrease by low microvascular density, and the decrease of some angiogenic mediators such as VEGF-1 and VEGF-2 (Otake et al, 2009). In addition, in animal models, ARB or ACEi enhance the effect of usual chemotherapies: in murine hepatocarcinoma in association to interferon- (Noguchi et al, 2003), in mouse bladder cancer combined with cis-platin by further suppressing angiogenesis (Kosugi et al, 2009), by enhancing effects of radiation (Ohnuma et al, 2009), or in addition with $\mathrm{K} 2$ vitamin in hepatocellular carcinoma in rats (Yoshiji et al, 2006). Furthermore, few recent clinical trials reported that ARB could improve cancer prognosis when used in association with standard chemotherapies. In a report of three cases of metastatic RCCC, $\mathrm{ARB}$ was associated with cimetidine and cyclo-oxygenase 2 inhibitors allowing prolonged partial remission (Tatokoro et al, 2008). In a retrospective cohort study on advanced non-small-cell lung cancer, ARB or ACEi were statistically associated with longer patient survival when used with first-line platinum-based chemotherapy (Wilop et al, 2009).

One pharmacological AT2-R blocker (PD123319) has been used with controversial results. It can facilitate tumourogenesis by Pax2 activation and resulted in prostatic cancer-cell proliferation (Bose et al, 2009). In a gastric cancer model, the same AT2-R blocker induced cell proliferation and cell viability, but inhibited cell invasion (Carl-McGrath et al, 2007). In recent work on pancreatic cancer cells, it also enhanced production of the inflammatory mediator MCP-1, which promotes tumour invasion (Chehl et al, 2009). According to this tissue specificity of AT2-R expression and AT2-R blocker effect, overexpression of AT2-R in the RCCC may suggest a different role of AT2-R and in consequence, different actions of its blocker.

For RCCC, $40 \%$ of the patients develop distant metastases with poor prognosis. As RCCC are highly vascularises cancers, with high secretion of VEGF (Rioux-Leclercq et al, 2007), recent therapies are focused on anti-angiogenic drugs (Rini, 2009): antiVEGF antibody (bevacizumab) (Rini et al, 2008) or tyrosine kinase inhibitors (Sunitinib, sorafenib) (Motzer et al, 2007; Negrier et al, 2009). These drugs already significantly increased patient survival but PFS is still counted in months (Motzer et al, 2007). Our study demonstrates that AT1-R and AT2-R are overexpressed in RCCC, and that this overexpression correlates with tumour aggressiveness and PFS. In consequence, AT1-R and AT2-R can be used as new prognosis factors for RCCC but ARB and ACEi can also be suggested as new adjuvant pathway for RCCC therapy. Indeed, these results, in addition to already-published experimental and clinical data on other cancer types, suggest that blocking RAS might be a way to decrease RCCC growth, neovascularization and metastasis dissemination. Experimental in vitro and in vivo studies with $\mathrm{ARB}$ and ACEi, in addition to antiangiogenic therapies, are the following steps to confirm our hypothesis.

\section{CONCLUSION}

Our study first report that AT1-R and AT2-R protein expression can be used as new prognosis factors in RCCC, strongly related to tumour aggressiveness and worse PFS. These results support the hypothesis that ARB and ACEi could represent interesting adjuvant treatments in metastatic RCCC. 


\section{ACKNOWLEDGEMENTS}

The authors would like to thank Dr Stuart T Fraser for his help in revising English language, and INCa (Institut National du Cancer),
Brittany region, the scientific committee of the Rennes medical faculty and the French 'Sociéte de Néphrologie' for their fundings.

\section{REFERENCES}

Arafat HA, Gong Q, Chipitsyna G, Rizvi A, Saa CT, Yeo CJ (2007) Antihypertensives as novel antineoplastics: angiotensin-I-converting enzyme inhibitors and angiotensin II type 1 receptor blockers in pancreatic ductal adenocarcinoma. J Am Coll Surg 204: 996-1005; discussion 1005 - 1006

Arendshorst WJ, Brannstrom K, Ruan X (1999) Actions of angiotensin II on the renal microvasculature. J Am Soc Nephrol 10(Suppl 11): S149-S161

Arrieta O, Pineda-Olvera B, Guevara-Salazar P, Hernandez-Pedro N, Morales-Espinosa D, Ceron-Lizarraga TL, Gonzalez-De la Rosa CH, Rembao D, Segura-Pacheco B, Sotelo J (2008) Expression of AT1 and AT2 angiotensin receptors in astrocytomas is associated with poor prognosis. Br J Cancer 99: $160-166$

Bose SK, Gibson W, Giri S, Nath N, Donald CD (2009) Angiotensin II up-regulates PAX2 oncogene expression and activity in prostate cancer via the angiotensin II type I receptor. Prostate 69: 1334-1342

Cao Z, Kelly DJ, Cox A, Casley D, Forbes JM, Martinello P, Dean R, Gilbert RE, Cooper ME (2000) Angiotensin type 2 receptor is expressed in the adult rat kidney and promotes cellular proliferation and apoptosis. Kidney Int 58: $2437-2451$

Carl-McGrath S, Ebert MP, Lendeckel U, Rocken C (2007) Expression of the local Angiotensin II system in gastric cancer may facilitate lymphatic invasion and nodal spread. Cancer Biol Ther 6(8): 1218-1226

Chatterjee PK, Weerackody RP, Mistry SK, Hawksworth GM, McLay JS (1997) Selective antagonism of the AT1 receptor inhibits angiotensin II stimulated DNA and protein synthesis in primary cultures of human proximal tubular cells. Kidney Int 52: 699-705

Chehl N, Gong Q, Chipitsyna G, Aziz T, Yeo CJ, Arafat HA (2009) Angiotensin II regulates the expression of monocyte chemoattractant protein-1 in pancreatic cancer cells. J Gastrointest Surg 13(12): $2189-2200$

de Groot-Besseling RR, Ruers TJ, van Kraats AA, Poelen GJ, Ruiter DJ, de Waal RM, Westphal JR (2004) Anti-tumour activity of a combination of plasminogen activator and captopril in a human melanoma xenograft model. Int I Cancer 112: 329-334

De la Iglesia Inigo S, Lopez-Jorge CE, Gomez-Casares MT, Lemes Castellano A, Martin Cabrera P, Lopez Brito J, Suarez Cabrera A, Molero Labarta T (2009) Induction of apoptosis in leukemic cell lines treated with captopril, trandolapril and losartan: a new role in the treatment of leukaemia for these agents. Leuk Res 33: 810-816

Friis S, Sorensen HT, Mellemkjaer L, McLaughlin JK, Nielsen GL, Blot WJ, Olsen JH (2001) Angiotensin-converting enzyme inhibitors and the risk of cancer: a population-based cohort study in Denmark. Cancer 92: $2462-2470$

Fuhrman SA, Lasky LC, Limas C (1982) Prognostic significance of morphologic parameters in renal cell carcinoma. Am J Surg Pathol 6: $655-663$

Fujiyama S, Matsubara H, Nozawa Y, Maruyama K, Mori Y, Tsutsumi Y, Masaki H, Uchiyama Y, Koyama Y, Nose A, Iba O, Tateishi E, Ogata N, Jyo N, Higashiyama S, Iwasaka T (2001) Angiotensin AT(1) and AT(2) receptors differentially regulate angiopoietin-2 and vascular endothelial growth factor expression and angiogenesis by modulating heparin binding-epidermal growth factor (EGF)-mediated EGF receptor transactivation. Circ Res 88: $22-29$

Goldfarb DA, Diz DI, Tubbs RR, Ferrario CM, Novick AC (1994) Angiotensin II receptor subtypes in the human renal cortex and renal cell carcinoma. J Urol 151: 208-213

Greco S, Muscella A, Elia MG, Salvatore P, Storelli C, Mazzotta A, Manca C, Marsigliante S (2003) Angiotensin II activates extracellular signal regulated kinases via protein kinase $\mathrm{C}$ and epidermal growth factor receptor in breast cancer cells. J Cell Physiol 196: $370-377$

Herr D, Rodewald M, Fraser HM, Hack G, Konrad R, Kreienberg R, Wulff C (2008) Potential role of Renin-Angiotensin-system for tumor angiogenesis in receptor negative breast cancer. Gynecol Oncol 109: 418-425

Ino $K$, Shibata K, Kajiyama $H$, Yamamoto E, Nagasaka T, Nawa A, Nomura S, Kikkawa F (2006) Angiotensin II type 1 receptor expression in ovarian cancer and its correlation with tumour angiogenesis and patient survival. $\mathrm{Br} J$ Cancer 94: 552-560

Juillerat-Jeanneret L, Celerier J, Chapuis Bernasconi C, Nguyen G, Wostl W, Maerki HP, Janzer RC, Corvol P, Gasc JM (2004) Renin and angiotensinogen expression and functions in growth and apoptosis of human glioblastoma. Br J Cancer 90: 1059-1068

Kosaka T, Miyajima A, Shirotake S, Kikuchi E, Hasegawa M, Mikami S, Oya M (2010) Ets-1 and hypoxia inducible factor-1alpha inhibition by angiotensin II type-1 receptor blockade in hormone-refractory prostate cancer. Prostate 70: $162-169$

Kosugi M, Miyajima A, Kikuchi E, Kosaka T, Horiguchi Y, Murai M, Oya M (2009) Angiotensin II type 1 receptor antagonist enhances cis-dichlorodiammineplatinum-induced cytotoxicity in mouse xenograft model of bladder cancer. Urology 73: 655-660

Lever AF, Hole DJ, Gillis CR, McCallum IR, McInnes GT, MacKinnon PL, Meredith PA, Murray LS, Reid JL, Robertson JW (1998) Do inhibitors of angiotensin-I-converting enzyme protect against risk of cancer? Lancet 352: $179-184$

Li P, Kondo T, Numaguchi Y, Kobayashi K, Aoki M, Inoue N, Okumura K, Murohara T (2008) Role of bradykinin, nitric oxide, and angiotensin II type 2 receptor in imidapril-induced angiogenesis. Hypertension 51: $252-258$

Matsubara H, Sugaya T, Murasawa S, Nozawa Y, Mori Y, Masaki H, Maruyama K, Tsutumi Y, Shibasaki Y, Moriguchi Y, Tanaka Y, Iwasaka T, Inada M (1998) Tissue-specific expression of human angiotensin II AT1 and AT2 receptors and cellular localization of subtype mRNAs in adult human renal cortex using in situ hybridization. Nephron 80: $25-34$

Miyajima A, Kosaka T, Asano T, Seta K, Kawai T, Hayakawa M (2002) Angiotensin II type I antagonist prevents pulmonary metastasis of murine renal cancer by inhibiting tumor angiogenesis. Cancer Res 62: $4176-4179$

Motzer RJ, Hutson TE, Tomczak P, Michaelson MD, Bukowski RM, Rixe O, Oudard S, Negrier S, Szczylik C, Kim ST, Chen I, Bycott PW, Baum CM, Figlin RA (2007) Sunitinib versus interferon alfa in metastatic renal-cell carcinoma. $N$ Engl J Med 356: $115-124$

Negrier S, Jager E, Porta C, McDermott D, Moore M, Bellmunt J, Anderson S, Cihon F, Lewis J, Escudier B, Bukowski R (2009) Efficacy and safety of sorafenib in patients with advanced renal cell carcinoma with and without prior cytokine therapy, a subanalysis of TARGET. Med Oncol 27(3): $899-906$

Neo JH, Malcontenti-Wilson C, Muralidharan V, Christophi C (2007) Effect of ACE inhibitors and angiotensin II receptor antagonists in a mouse model of colorectal cancer liver metastases. J Gastroenterol Hepatol 22: $577-584$

Noguchi R, Yoshiji H, Ikenaka Y, Namisaki T, Kitade M, Kaji K, Yoshii J, Yanase K, Yamazaki M, Tsujimoto T, Kawaratani H, Fukui H (2009) Synergistic inhibitory effect of gemcitabine and angiotensin type-1 receptor blocker, losartan, on murine pancreatic tumor growth via antiangiogenic activities. Oncol Rep 22: 355-360

Noguchi R, Yoshiji H, Kuriyama S, Yoshii J, Ikenaka Y, Yanase K, Namisaki T, Kitade M, Yamazaki M, Mitoro A, Tsujinoue H, Imazu H, Masaki T, Fukui H (2003) Combination of interferon-beta and the angiotensin-converting enzyme inhibitor, perindopril, attenuates murine hepatocellular carcinoma development and angiogenesis. Clin Cancer Res 9: 6038-6045

Norwood VF, Craig MR, Harris JM, Gomez RA (1997) Differential expression of angiotensin II receptors during early renal morphogenesis. Am J Physiol 272: R662 - R668

Nouet S, Nahmias C (2000) Signal transduction from the angiotensin II AT2 receptor. Trends Endocrinol Metab 11: $1-6$

Ohnuma Y, Toda M, Fujita M, Hosono K, Suzuki T, Ogawa Y, Amano H, Kitasato H, Hayakawa K, Majima M (2009) Blockade of an angiotensin type I receptor enhances effects of radiation on tumour growth and tumor-associated angiogenesis by reducing vascular endothelial growth factor expression. Biomed Pharmacother 63: 136-145 
Oken MM, Creech RH, Tormey DC, Horton J, Davis TE, McFadden ET, Carbone PP (1982) Toxicity and response criteria of the Eastern Cooperative Oncology Group. Am J Clin Oncol 5: 649-655

Otake AH, Mattar AL, Freitas HC, Machado CM, Nonogaki S, Fujihara CK, Zatz R, Chammas R (2009) Inhibition of angiotensin II receptor 1 limits tumor-associated angiogenesis and attenuates growth of murine melanoma. Cancer Chemother Pharmacol 66(1): 79-87

Puddefoot JR, Udeozo UK, Barker S, Vinson GP (2006) The role of angiotensin II in the regulation of breast cancer cell adhesion and invasion. Endocr Relat Cancer 13: 895-903

Rhodes DR, Ateeq B, Cao Q, Tomlins SA, Mehra R, Laxman B, KalyanaSundaram S, Lonigro RJ, Helgeson BE, Bhojani MS, Rehemtulla A, Kleer CG, Hayes DF, Lucas PC, Varambally S, Chinnaiyan AM (2009) AGTR1 overexpression defines a subset of breast cancer and confers sensitivity to losartan, an AGTR1 antagonist. Proc Natl Acad Sci USA 106: $10284-10289$

Richard DE, Berra E, Pouyssegur J (2000) Nonhypoxic pathway mediates the induction of hypoxia-inducible factor 1alpha in vascular smooth muscle cells. J Biol Chem 275: 26765-26771

Rini BI (2009) Vascular endothelial growth factor-targeted therapy in metastatic renal cell carcinoma. Cancer 115: 2306-2312

Rini BI, Halabi S, Rosenberg JE, Stadler WM, Vaena DA, Ou SS, Archer L, Atkins JN, Picus J, Czaykowski P, Dutcher J, Small EJ (2008) Bevacizumab plus interferon alfa compared with interferon alfa monotherapy in patients with metastatic renal cell carcinoma: CALGB 90206. J Clin Oncol 26: 5422-5428

Rioux-Leclercq N, Fergelot P, Zerrouki S, Leray E, Jouan F, Bellaud P, Epstein JI, Patard JJ (2007) Plasma level and tissue expression of vascular endothelial growth factor in renal cell carcinoma: a prospective study of 50 cases. Hum Pathol 38: 1489-1495

Rocken C, Rohl FW, Diebler E, Lendeckel U, Pross M, Carl-McGrath S, Ebert MP (2007) The angiotensin II/angiotensin II receptor system correlates with nodal spread in intestinal type gastric cancer. Cancer Epidemiol Biomarkers Prev 16: $1206-1212$

Stoll M, Steckelings UM, Paul M, Bottari SP, Metzger R, Unger T (1995) The angiotensin AT2-receptor mediates inhibition of cell proliferation in coronary endothelial cells. J Clin Invest 95: 651-657

Suganuma T, Ino K, Shibata K, Kajiyama H, Nagasaka T, Mizutani S, Kikkawa $F$ (2005) Functional expression of the angiotensin II type 1 receptor in human ovarian carcinoma cells and its blockade therapy resulting in suppression of tumour invasion, angiogenesis, and peritoneal dissemination. Clin Cancer Res 11: 2686-2694

Takeda H, Kondo S (2001) Differences between squamous cell carcinoma and keratoacanthoma in angiotensin type-1 receptor expression. Am J Pathol 158: 1633-1637
Tamura M, Yan H, Zegarra-Moro O, Edl J, Oursler S, Chard-Bergstrom C, Andrews G, Kanehira T, Takekoshi S, Mernaugh R (2008) Specific single chain variable fragment $(\mathrm{ScFv})$ antibodies to angiotensin II $\mathrm{AT}(2)$ receptor: evaluation of the angiotensin II receptor expression in normal and tumor-bearing mouse lung. J Mol Histol 39: 351-358

Tatokoro M, Fujii Y, Kawakami S, Fukui N, Komai Y, Saito K, Koga F, Morimoto S, Fukui I, Kihara K (2008) Favorable response to combination treatment of cimetidine, cyclooxygenase- 2 inhibitor and renin-angiotensin system inhibitor in metastatic renal cell carcinoma: Report of three cases. Int I Urol 15: $848-850$

Uemura $\mathrm{H}$, Ishiguro $\mathrm{H}$, Nakaigawa $\mathrm{N}$, Nagashima $\mathrm{Y}$, Miyoshi $\mathrm{Y}$, Fujinami K, Sakaguchi A, Kubota Y (2003) Angiotensin II receptor blocker shows antiproliferative activity in prostate cancer cells: a possibility of tyrosine kinase inhibitor of growth factor. Mol Cancer Ther 2: $1139-1147$

Wang L, Cai SR, Zhang CH, He YL, Zhan WH, Wu H, Peng JJ (2008) Effects of angiotensin-converting enzyme inhibitors and angiotensin II type 1 receptor blockers on lymphangiogenesis of gastric cancer in a nude mouse model. Chin Med J (Engl) 121: 2167-2171

Weerackody RP, Chatterjee PK, Mistry SK, McLaren J, Hawksworth GM, McLay JS (1997) Selective antagonism of the AT1 receptor inhibits the effect of angiotensin II on DNA and protein synthesis of rat proximal tubular cells. Exp Nephrol 5: 253-262

Wilop S, von Hobe S, Crysandt M, Esser A, Osieka R, Jost E (2009) Impact of angiotensin I converting enzyme inhibitors and angiotensin II type 1 receptor blockers on survival in patients with advanced non-small-cell lung cancer undergoing first-line platinum-based chemotherapy. $J$ Cancer Res Clin Oncol 135(10): 1429-1435

Yoshiji H, Kuriyama S, Fukui H (2002) Perindopril: possible use in cancer therapy. Anticancer Drugs 13: $221-228$

Yoshiji H, Kuriyama S, Noguchi R, Yoshii J, Ikenaka Y, Yanase K, Namisaki T, Kitade M, Yamazaki M, Akahane T, Asada K, Tsujimoto T, Uemura M, Fukui H (2006) Amelioration of carcinogenesis and tumor growth in the rat liver by combination of vitamin K2 and angiotensinconverting enzyme inhibitor via anti-angiogenic activities. Oncol Rep 15: $155-159$

Yoshiji H, Kuriyama S, Noguchi R, Yoshii J, Ikenaka Y, Yanase K, Namisaki T, Kitade M, Yamazaki M, Masaki T, Fukui H (2005) Combination of vitamin $\mathrm{K} 2$ and the angiotensin-converting enzyme inhibitor, perindopril, attenuates the liver enzyme-altered preneoplastic lesions in rats via angiogenesis suppression. J Hepatol 42: 687-693

Zhao Y, Chen X, Cai L, Yang Y, Sui G, Fu S (2010) Angiotensin II/Angiotensin II type I receptor (AT1R) signaling promotes MCF-7 breast cancer cells survival via PI3-kinase/Akt pathway. J Cell Physiol 225(1): $168-173$ 